\title{
Structure of the mouthparts and alimentary canal of Eusomus ovulum Germar, 1824 (Coleoptera: Curculionidae)
}

\author{
Nurcan Özyurt Koçakoğlu ${ }^{1}$, Selami Candan ${ }^{1 *}$, Mahmut Erbey² \\ ${ }^{1}$ Gazi University, Science Faculty, Department of Biology, 06500 Ankara, Turkey. \\ ${ }^{2}$ Ahi Evran University, Faculty of Arts and Sciences, Department of Molecular Biology and Genetics, 40100 Kirșehir, Turkey.
}

\section{A R T I C L E I N F O}

\section{Article history:}

Received 08 January 2020

Accepted 02 September 2020

Available online 07 October 2020

Associate Editor: Rodrigo Feitosa

\section{Keywords:}

Mouthparts

Foregut

Midgut

Hindgut

Histology

Morphology

\begin{abstract}
A B S T R A C T
The structural morphology of mouthparts, the distribution of sensilla on the mouthparts, histology, and the morphology of the alimentary canal in adult Eusomus ovulum Germar, 1824 were examined under both light and scanning electron microscopy (SEM). The mouthparts are located at the tip of the short rostrum. The mandibles, the maxillae and the labial palpi comprise the moveable mouthparts. Also there are sensillae which act as chemoreceptors on the terminal segment of the snout.

Alimentary canal of adult E. ovulum is divided into three main regions, foregut, midgut and hindgut. The first part of the gut is foregut, which is made up of a pharynx, esophagus, crop and proventriculus. The pharynx extends from the mouth, having muscle attachments radiating out from its surface and connecting with the head region. The esophagus is a narrow epithelial tube contiguous and posterior to the pharynx. The proventriculus consists of 8 sclerotized plates. The midgut, which is anteriorly bulbous with a tubular posterior half. Gastric caeca were found on the posterior region of the midgut. The midgut is surrounded by outer muscles and inner columnar epithelium. The hindgut has pylorus, ileum, colon, and rectum. There are three histological layers of the hindgut from lumen to hemocoel: intima, epithelium, muscles. The hindgut has a cryptonephridial attachment for the six Malpighian tubes anterior to the rectum.

The aim of the present study is to contribute information on the morphology of mouthparts, and the morphology and histology of the alimentary tract of the insect.
\end{abstract}

\section{Introduction}

Curculionidae is one of the largest families of Coleoptera. Almost all species of Curculionidae are phytophagous according to Ross (1963). Larvae and adults feed on various plant organs: roots, stems, leaves and fruits. Some species can cause economic losses (Hoffmann, 1950; Mihajlova, 1978; Caldara, 1990). Eusomus ovulum uses many plants as hosts, and it has been reported to cause significant damage, especially of forage clover. Some host plants of E. ovulum are Amygdalus communis L., Avena sativa L., Centaurea sp., Medicago sativa L., Onobrychis sativa Lam., and Vicia sativa L (Lodos et al., 2003; Bolu, 2016).

To provide insight into feeding mechanisms and to provide characters for use in phylogenetic and taxonomic studies, research on mouthpart morphology is needed. Studies on mouthpart morphology can also reveal previously unknown feeding habits of insects. While most beetles have mouthparts designed for chewing solid food, Curculionoidea have mouthparts at the end of a distinct snout for boring holes for egg-

\footnotetext{
* Corresponding author.

E-mail: scandan@gazi.edu.tr(S. Candan).
}

laying as well as for feeding (Moon, 2015; Chen et al., 2016). Previous studies of the mouthparts in Curculionoidea have mostly focused on the external comparative morphology within a tribe or family with the aim of elucidating their feeding mechanisms or taxonomic relationships (Chen et al., 2016).

In addition to differences in mouthpart morphology, an insect's alimentary canal can show great variation due to diversity in food materials consumed (Snodgrass, 1993; Sarwade and Bhawane, 2013). Like other insects, the alimentary canal of beetles in divisible into three main regions: the foregut, which is ectodermal in origin, midgut, which is endodermal in origin and hindgut, which is also ectodermal in origin (Sinha, 1958; Kasap, 1978; Snodgrass, 1993; Rubio et al., 2008; Sousa et al., 2013). All these regions are responsible for ingestion, storage, digestion, absorption of food and water balance (Calder, 1989; Romoser and Stoffolano, 1998; Bu and Chen, 2009; Aldigail et al., 2013).

The foregut of coleopterans, generally tubular, is composed of a narrow pharynx opening into the tubular esophagus. It is narrow anteriorly but may be distended posteriorly to form a crop and proventriculus (Ekis 
and Gupta, 1971; Sarwade and Bhawane, 2013; Sousa et al., 2013). In many insects, the crop acts as a storage organ (Crowson, 1981) whereas the muscular proventriculus is the site where food particles are broken or filtered to the midgut (Kissinger, 1963; Serrão, 2005, 2007).

The midgut is generally the longest part of the gut, and is occasionally referred to as the stomach or ventriculus. The midgut lacks a chitinous lining. Most digestion occurs in this region. Epithelial cells of the midgut produce and secrete digestive enzymes and then the resultant nutrients are reabsorbed (Gilmour, 1961; Dadd, 1970; Wigglesworth, 1972; Gullan and Cranston, 2005; Sarwade and Bhawane, 2013).

The hindgut, the final part of the digestive system, is subdivided into the pylorus, the ileum, followed by the colon and rectum and ending exteriorly with the anus. The hindgut is lined with a thin layer of cuticle (Sinha, 1958; Maddrell and Gardiner, 1980; Sarwade and Bhawane, 2013) with crucial roles in excretion and homeostasis (Garayoa et al., 1992; Serrão et al., 2004; Santos et al., 2009). Malpighian tubules arise at the junction of midgut and hindgut. Adult Coleopterans have a modified arrangement of Malpighian tubules which are responsible for efficient dehydration of feces before their elimination (Gullan and Cranston, 2005). Gullan and Cranston (2005) stated that Coleopterans generally have a cryptonephric system in which the distal ends of these tubules are held in contact with the rectal wall by the perinephric membrane.

E. ovulum is an economically important insect, so it can prove useful in providing basic information about the morphology of its mouthparts and alimentary tract can prove useful in controlling this species.

\section{Materials and methods}

Insect

Adult males and females of $E$. ovulum were collected from trifolium fields in Kırşehir (Özbağ), Turkey in May 2018. The weevils were placed in plastic containers with their food plant and were transported to the laboratory. In the laboratory, 25 insects were anesthetized with ethyl acetate. The head and alimentary canal of each insect were dissected in a $0.1 \mathrm{M}$ sodium phosphate buffer ( $\mathrm{pH}$ 7.2) under an Olympus SZX7 stereoscopic dissecting binocular microscope (SM) and photographed.

\section{Light Microscopy (LM)}

For histological investigations, the gross anatomical structures of dissected alimentary canals were removed and their gross anatomical structures were measured. Then the guts were fixed in $10 \%$ neutral formalin for 24 hours and then dehydrated for 1 hour in a progressive series of ethanol ( $50,70,80,90$ and $99,5 \%)$. The guts were subsequently transferred into xylol, and thereafter graded into solutions of decreasing xylol:paraffin. They were then embedded in pure paraffin which was cut into $7 \mu$ m-thick sections using a Microm HM 310 microtome. The sections were stained with hematoxylin and eosin ( $\mathrm{H} \& \mathrm{E})$ and then examined and photographed under an Olympus BX51 microscope.

\section{Scanning Electron Microscopy (SEM)}

For scanning electron microscopy examination, 10 adult females and males were randomly selected and anesthetized with ethyl acetate. The head with mouthparts and alimentary canal attached were first removed from the body under a dissecting stereomicroscope. Then samples were fixed in $2.5 \%$ glutaraldehyde ( $\mathrm{pH} 7.2$, sodium phosphate buffered), rinsed three times in sodium phosphate buffer and dehydrated by using an ethanol progressive series (50, 70, 80, 90 and 99.5\%). The samples were then transferred to hexamethyldisilazane and allowed to air dry; then the tissues were mounted on SEM stubs with doubleside sticky tape. They were subsequently covered with gold by using a Polaron SC 502 sputter coater. The stubs were examined with a SEM (JEOL JSM 6060 LV) and digital photos were taken.

\section{Results}

SEM of the external head morphology of E. ovulum shows a pair of compound eyes, a pair of antennae, and portions of the mouthparts (Figs. 1A and B). The mouthparts consist of a labrum, a pair of mandibles, a pair of maxillae and the labium. The labrum is the upper-most of the mouthparts and located on the midline. The labrum is a single, fused plate and on its' surface, there are a number of sensory setae. Beneath the labrum, a pair of jaw-like mandibles which serve as pincers can be seen. They are heavily sclerotized structures having cutting edges that move transversely to grasp or cut food (Fig. 1A). The anterior end is sharp and concave; the lower part is slightly protrudes the dorsal surface is granular and has long sensilla, and the mandibular scar is arched along the dorso-lateral axis of the mandible. The mandibular scar is prominent, wide, circular and pitted. Sensilla occur on the dorsal surface of the mandible (Figs. 1B and C). Mandibles are posteriorly attached to the arch-shaped rostrum (Figs. 1C and D). Together with the maxillae and the labial palpi they constitute the moveable mouthparts (Figs. 1B to F).

There are a pair of blade-like appendages, the maxillae, behind the mandibles. The paired maxillae are bilaterally located in longitudinal clefts on each side of the labium. Each maxilla is composed of cardo, stipes, palpifer and 3-segmented palpi. The cardo is short and flattened, the stipes and the palpifer are longitudinal (Fig. 1F). The first and second segments of the palpi are short, the terminal segment is long and bears three types of sensilla at their apices. There are five long and cylindrical sensilla (tip 1), located medially. The edge sensilla are short and pointed (tip 2). Additionally, there is a single sensilla (tip 3) like seta at the edge (Fig. $1 \mathrm{H}$ ).

The labium or lower lip is located ventrally and is fused along the midline. The labium is a single structure that is equivalent to the floor of the mouth although it is formed from two fused secondary maxillae (Fig. 1F). The prementum is broad and triangular, and has setae laterally. Each labial palp is composed of three smooth-surfaced segments. The basal two segments have single setae on the surface (Figs. 1E and F). The terminal segment has minute sensilla at their apices (Fig. 1G). The peduncule is very small and resembles the prementum (Fig. 1E).

Beyond the mouthparts is the alimentary canal which is tubular structure surroundeda by muscle and a tracheal network (Figs. 2A and B). The main structures of the alimentary canal of E. ovulum are easily distinguishable (Fig. 2A). It consists structurally of three distinct regions: the foregut, midgut and hindgut (Fig. 2A).

The foregut includes the pharynx, esophagus, crop and proventriculus (Figs. 2C, D). Muscles are attached dorsally and ventrally in the head and extend to the pharynx and esophagus (Fig. 2E). When the muscle is examined in detail, transverse striations are observed (Fig. 2F). The esophagus is elongate and terminates at the base of the crop.

A morphological cross section of the esophagus shows that it consists of lumen, intima, and a squamous epithelium which is thin, flat with external muscle layers (Fig. 3A). The intima is thick and sclerotized with folds (Fig. 3B). The intima has several well developed spine-like structures (Figs. 3C and D). Muscles are clearly visible along its length (Fig. 3B). Following the esophagus, we find the crop. In a morphological examination of the crop, bifurcated spines can be seen extending from the intima (Fig. 3F). The proventriculus follows after the crop but the transition limits are not clear (Fig. 3E). The proventriculus has a strong sclerotized intima and is the widest part of the foregut (Figs. 3G and H). 


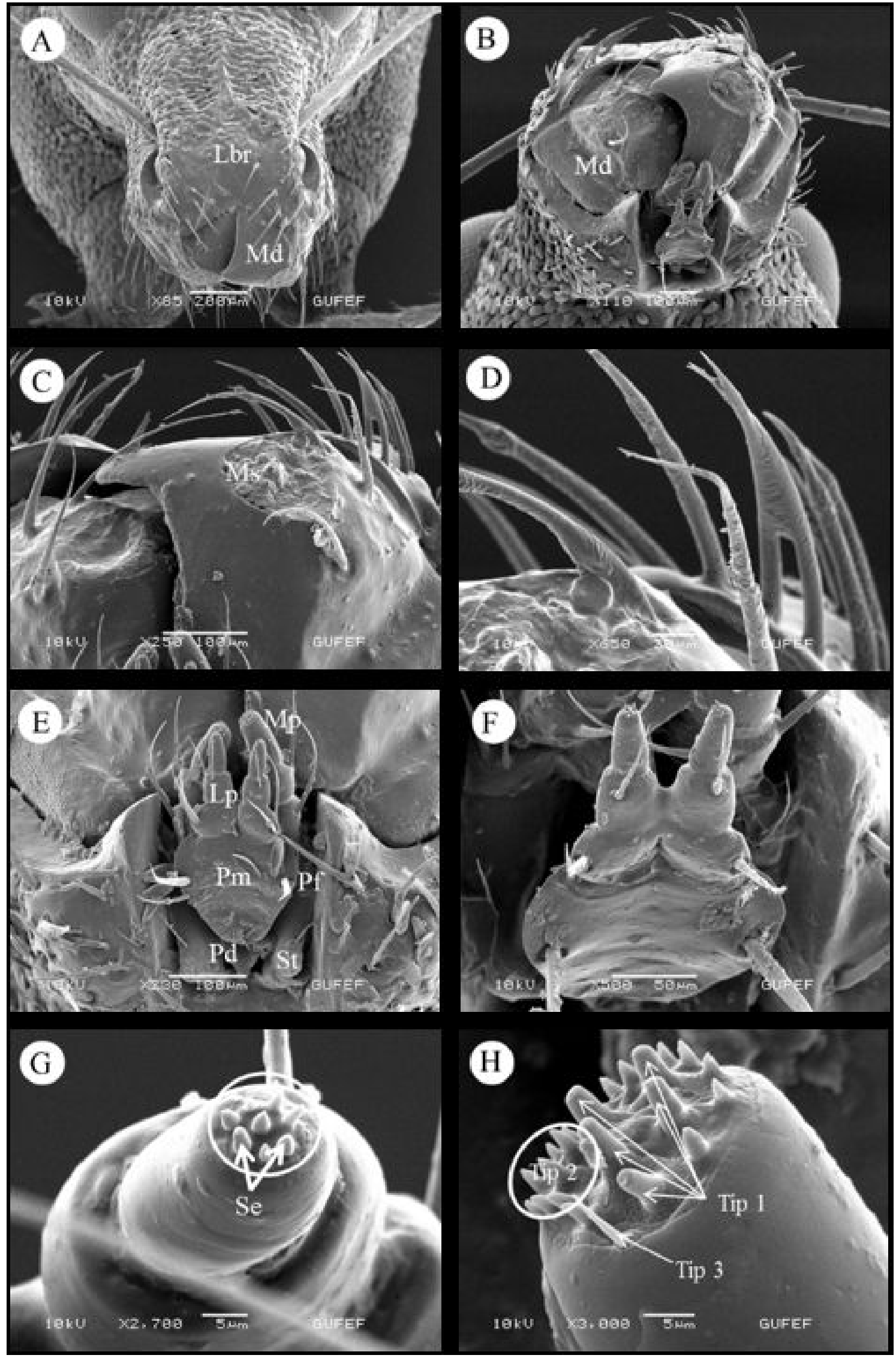

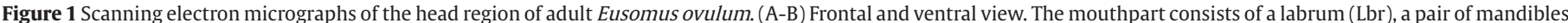

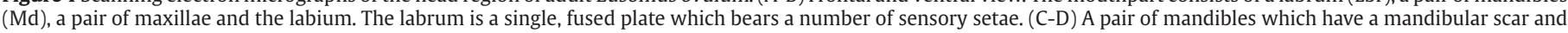

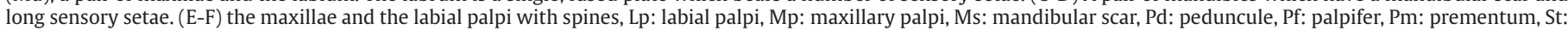
stripes. (G) Scanning electron micrographs of sensilla (Se) of distal segments of labial palpi. (H) The sensilla (tip 1,2,3) of distal segments of the maxillary palpi. 
Histologically the layers of proventriculus in sequence from inside to hemocoel are lumen, intima, monolayer epithelium and circular and longitudinal muscles (Figs. 3 I and J). The proventriculus is a spherical organ formed by eight sclerotized plates (Figs. 3I and K) each bearing
2 longitudinal brushes (Figs. 3I, J, L). Additionally, its outer surface is covered with numerous tracheae and tracheoles (Fig. 3H).

The midgut, the second part of alimentary canal has two distinguishable areas, anterior and posterior sections (Figs. 4A and 5A). The anterior

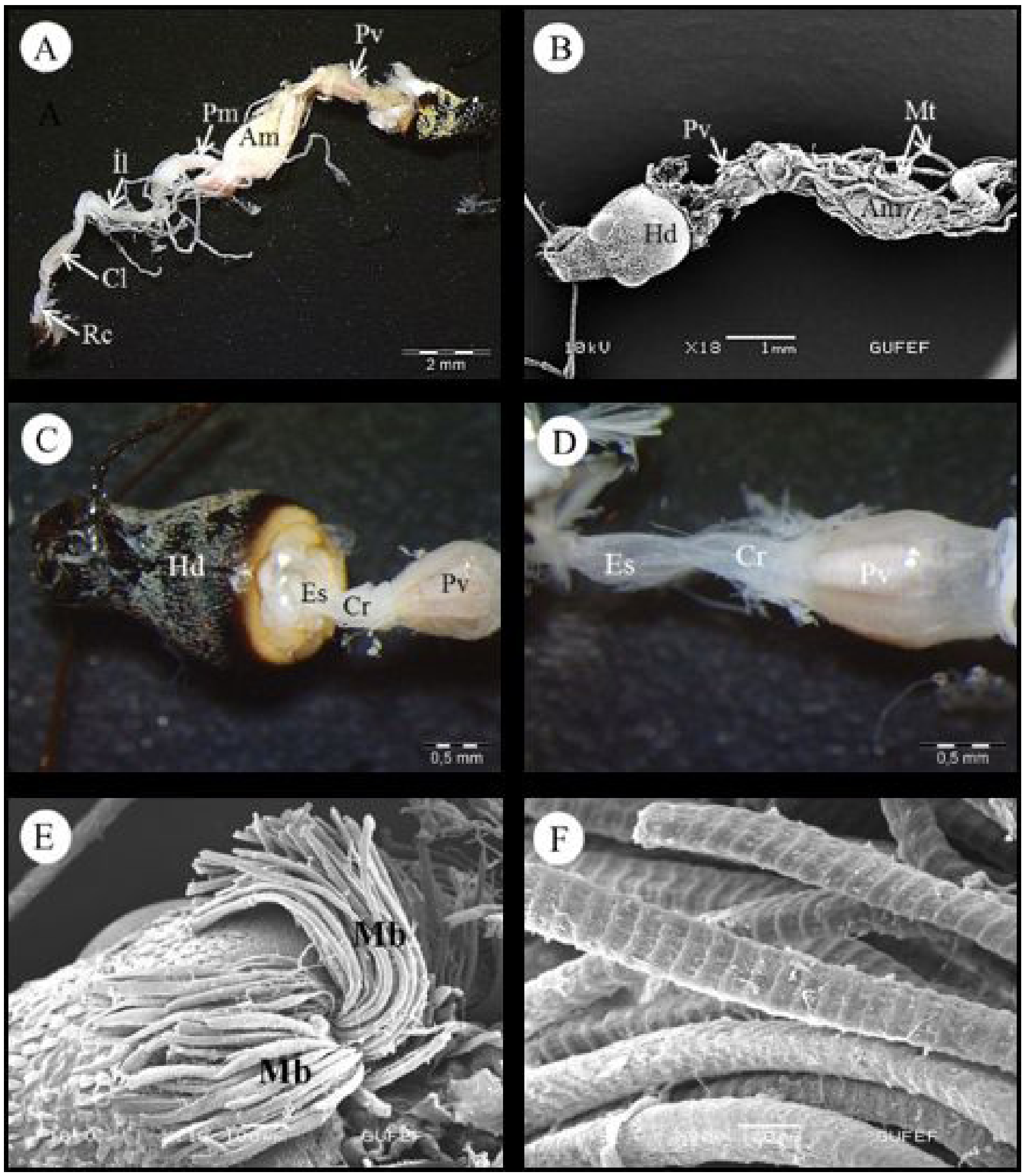

Figure 2 (A, B) General structure of the alimentary canal of adult E. ovulum (SM, SEM), (C, D) General view of regions of the foregut (SM) (E) Illustration of muscle bundles (Mb) near the pharynx and esophagus (SEM), (F) High magnification of individual muscles (SEM). (Am) anterior midgut, (Cl) colon, (Cr) crop, (Es) esophagus, (Hd) head capsule, (il) ileum, (Mt) Malpighian tubules, (Pm) posterior midgut, (Pv) proventriculus, (Rc) rectum. SEM-Scanning electron microscopy, SM-stereo microscope. 
region is a straight cylindrical structure (Figs. 4A and $B$ ) while the posterior region is coiled and occurs in the abdomen (Fig. 5A). It was observed that Malpighian tubules extend along the anterior midgut surface and there are tracheae on the surface (Fig. 4B). A cross section of the midgut shows that the midgut has a lumen, a single layer of columnar cells and numerous microvilli (Figs. 4C-F, 5B-D). The cells of epithelium are tall, columnar with distinct cell membranes, with centrally placed nuclei (Figs. 4D and 5B). Secretory granules can be seen in the midgut epithelial cells (Figs. 4F and 5D). Regenerative cells are found between the cylindrical epithelial cells (Fig. 4C). The posterior midgut wall produces numerous small pouch like gastric caeca (Figs. $5 \mathrm{E}$ and F). Tracheae can be seen among the gastric caeca (Fig. 5E). The gastric caeca, towards the end of the posterior midgut, are short, tubular, cylindrical in shape, and their surface is smooth (Figs. 5E and F). In the histological examinations, each gastric caecum is surrounded by a monolayer of cuboidal epithelium. Oval nuclei of epithelial cells

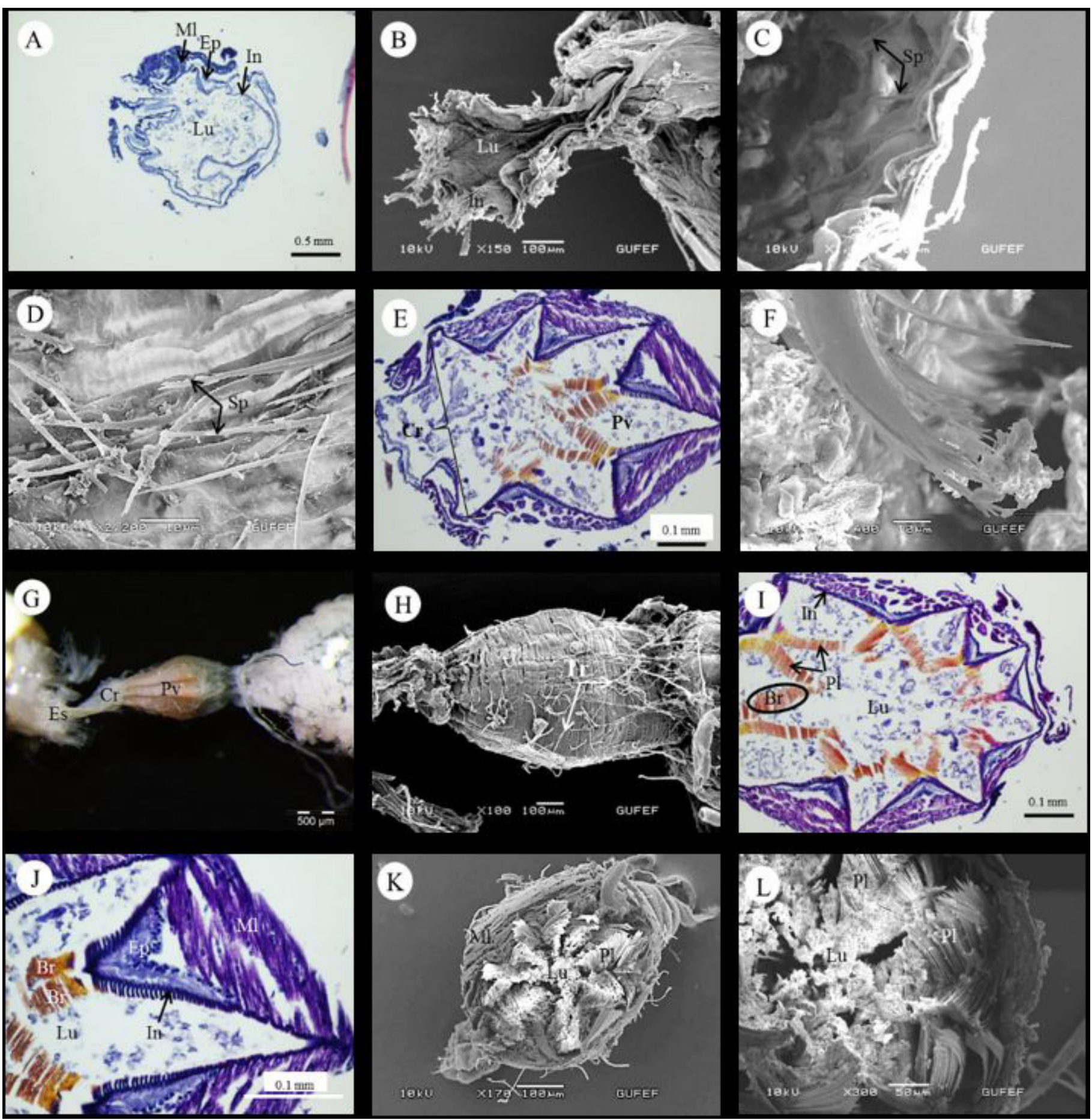

Figure 3 E. ovulum, adult: (A) Histological section of esophagus (LM) (H \& E), (B) Inner surface of esophagus (SEM), (C, D) The structure of the spines (Sp) on the inner surface of the esophagus (SEM), (E) Transition from the crop to proventriculus (LM) (H \& E). (F) Spines extending from the intima of the crop (SEM). (G) The general view of crop and chitinous plates in proventriculus (Pv) (SM), (H) Tracheae on the muscular surface of the proventriculus (SEM), (I, J) The cross section and the sclerotized plates (PI) consisting of a pair of brushes ( $\mathrm{Br}$ ) of the proventriculus ( $\mathrm{LM})(\mathrm{H} \& \mathrm{E})$, (K,L) View of the internal structure of proventriculus (SEM), (Cr) crop, (Ep) epithelium, (Lu) lumen, (In) intima, (MI) muscles, (Sp) spines, (Tr) tracheae. H \& E-hematoxylin and eosine, LM-Light microscopy, SEM-Scanning electron microscopy, SM-stereo microscope. 
are located in the central portion of the cells. There are microvilli in the apical ends of the epithelial cells. Their lumens are wide (Fig. 5B).

The hindgut forms the last region of the gut. It consists of pylorus, ileum, colon and rectum. Six Malpighian tubules join the alimentary canal at the junction of the posterior midgut and pylorus (Figs. 6A and B). Each Malpighian tubule is an unbranched tube, being uniform in diameter (Figs. 6A and B). By sectioning a Malpighian tubule one can observe the single layer of cuboidal epithelium (Figs. 6C and D). Externally,

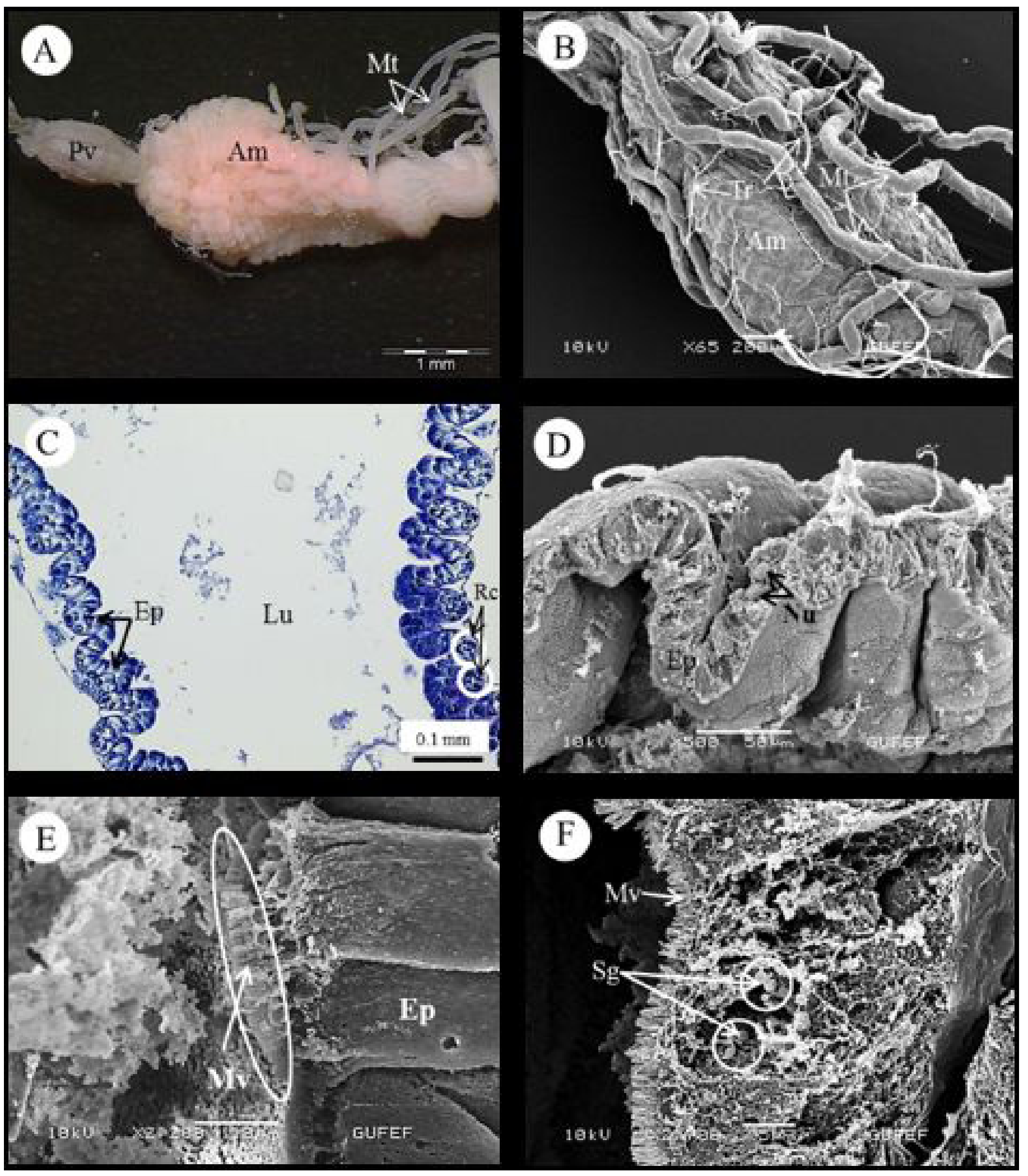

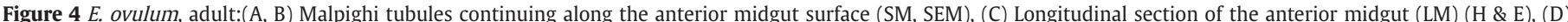

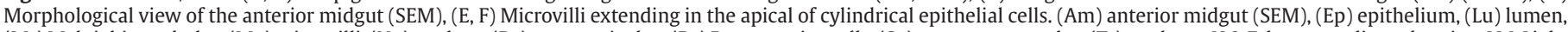

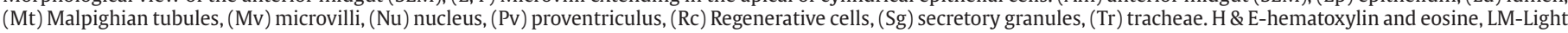
microscopy, SEM-Scanning electron microscopy, SM-stereo microscope. 
there is a thin connective sheath. On its surface, numerous tracheae and tracheoles are seen (Fig. 6C). The ends of Malpighian tubules lie parallel to the outer surfaces of the colon and rectum. Malpighian tubules present in this region have a cryptonephric arrangement. The ileum is located posterior to the pylorus (Figs. 6E and F). Histologically and morphologically, the epithelium of the ileum consists of cuboidal cells. The nuclei of the epithelial cells are round. The intima is thin and sclerotized (Figs. 6G and $\mathrm{H}$ ).

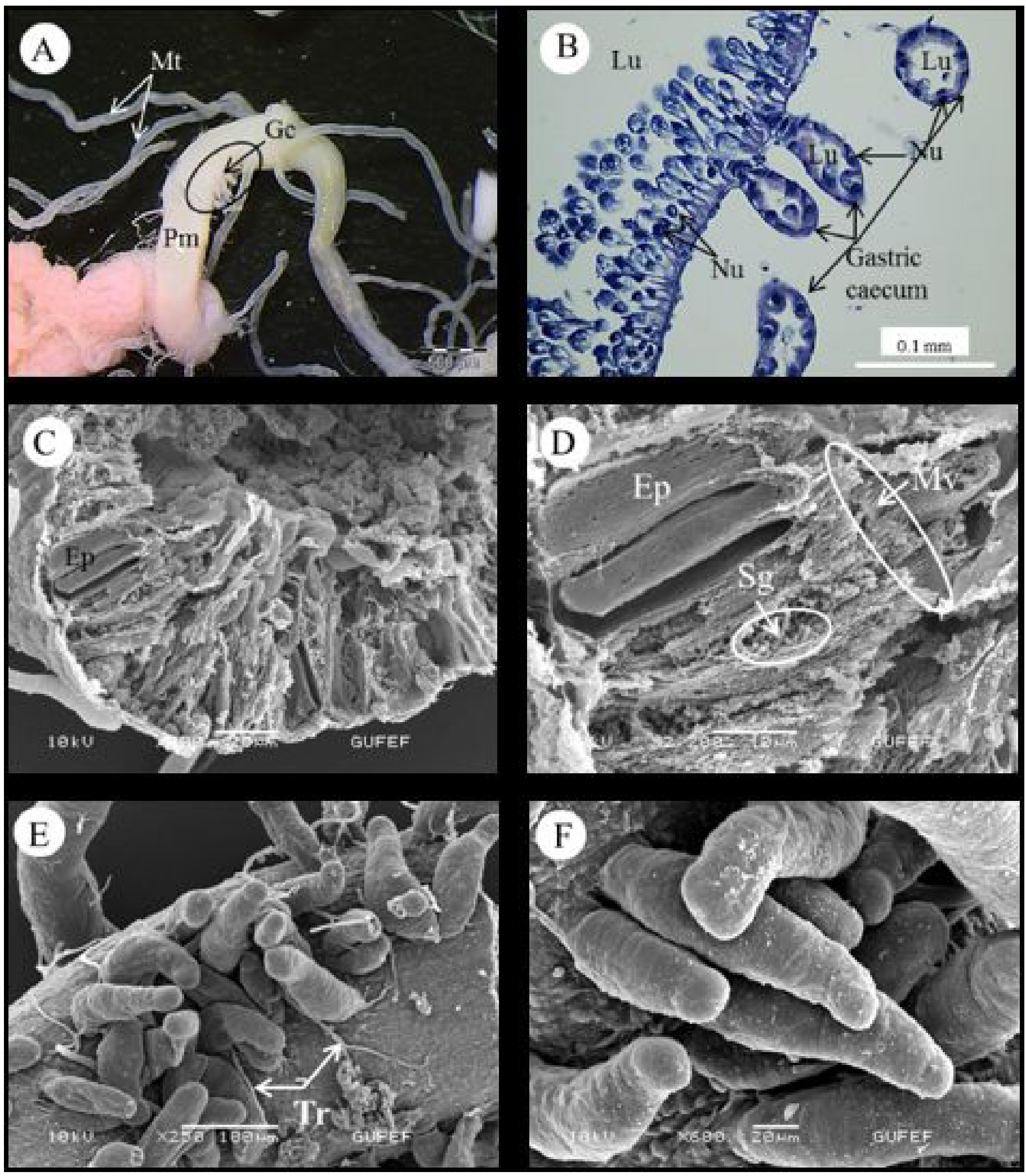

Figure 5 E. ovulum, adult: (A) Over view of the posterior midgut (Pm) (SM). (B) Histological section of the posterior midgut and gastric caeca (LM) (H \& E). (C, D) Microvilli extend into lumen from the apical surfaces of epithelial cells in posterior midgut (SEM). (E, F) Morphological view of the gastric caeca (Gc) (SEM). (Ep) epithelium, (Lu) lumen, (Mt) Malpighian tubules, (Mv) microvilli, (Nu) nucleus, (Sg) secretory granules, (Tr) tracheae. H \& E-hematoxylin and eosine, LM-Light microscopy, SEM-Scanning electron microscopy, SM-stereo microscope. 
The ileum joins with colon. Malpighian tubules can be clearly distinguished from the outer surface of the colon (Figs. 7A and B). Histologically, the colon bears muscles and is lined internally with a thick layer of cuticular intima. The epithelium is made up of cuboidal cells (Figs. 7C and D). The colon surface is surrounded by muscles and covered with a large number of tracheae and tracheoles (Fig. 7B). The colon is anterior to and contiguous with the rectum (Fig. 7A). There are rectal pads on the outer surface of the rectum (Fig. 7E). Histologically
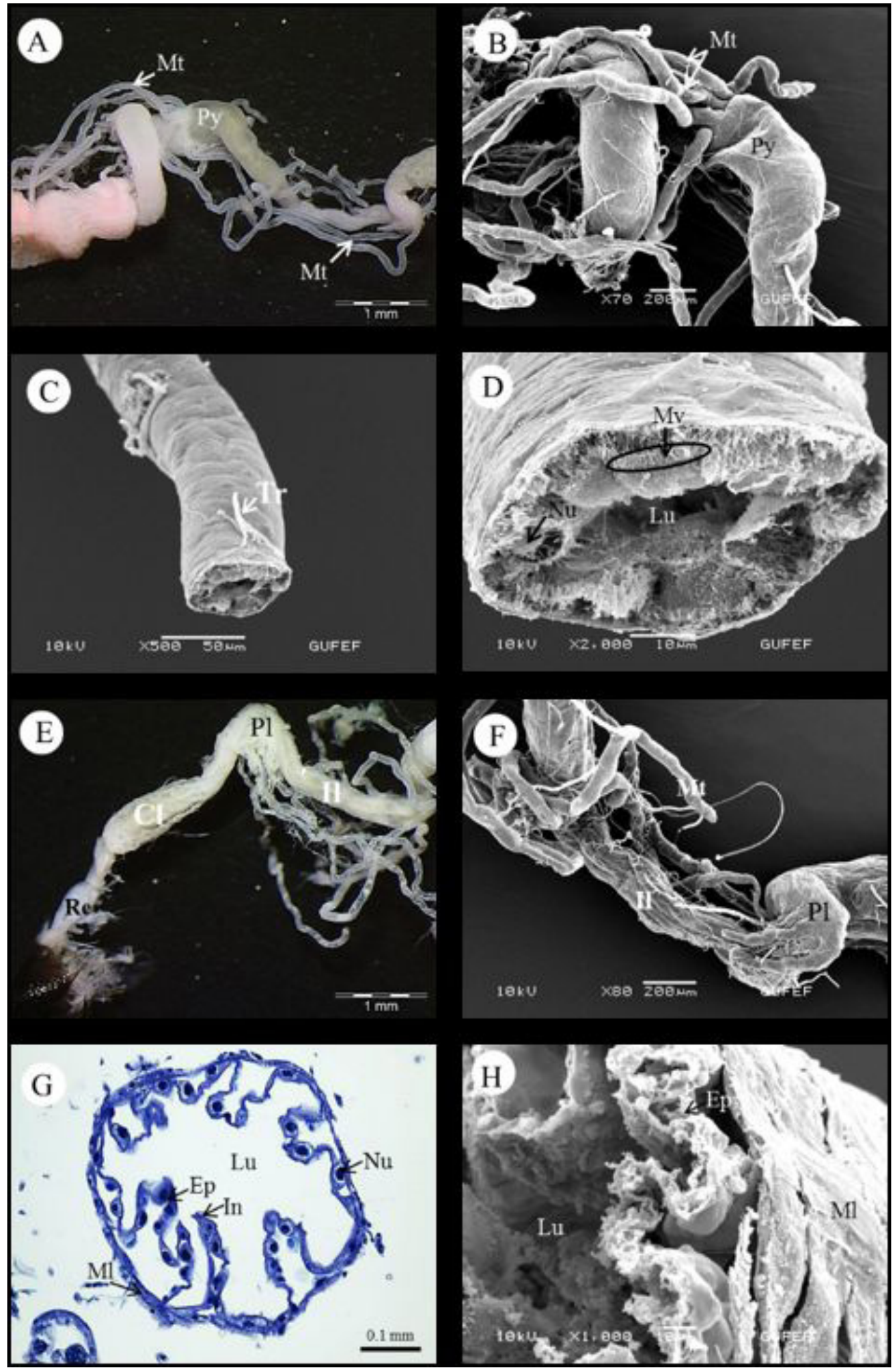

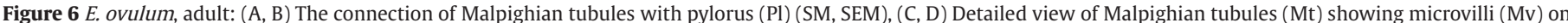

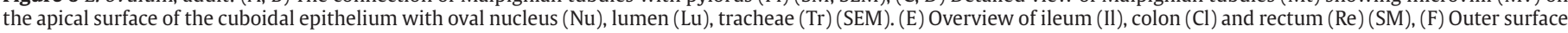

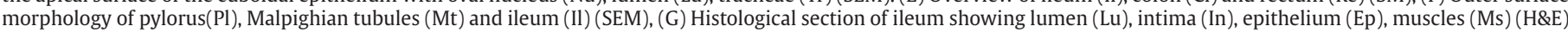

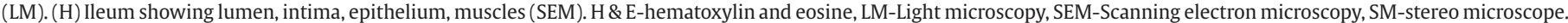




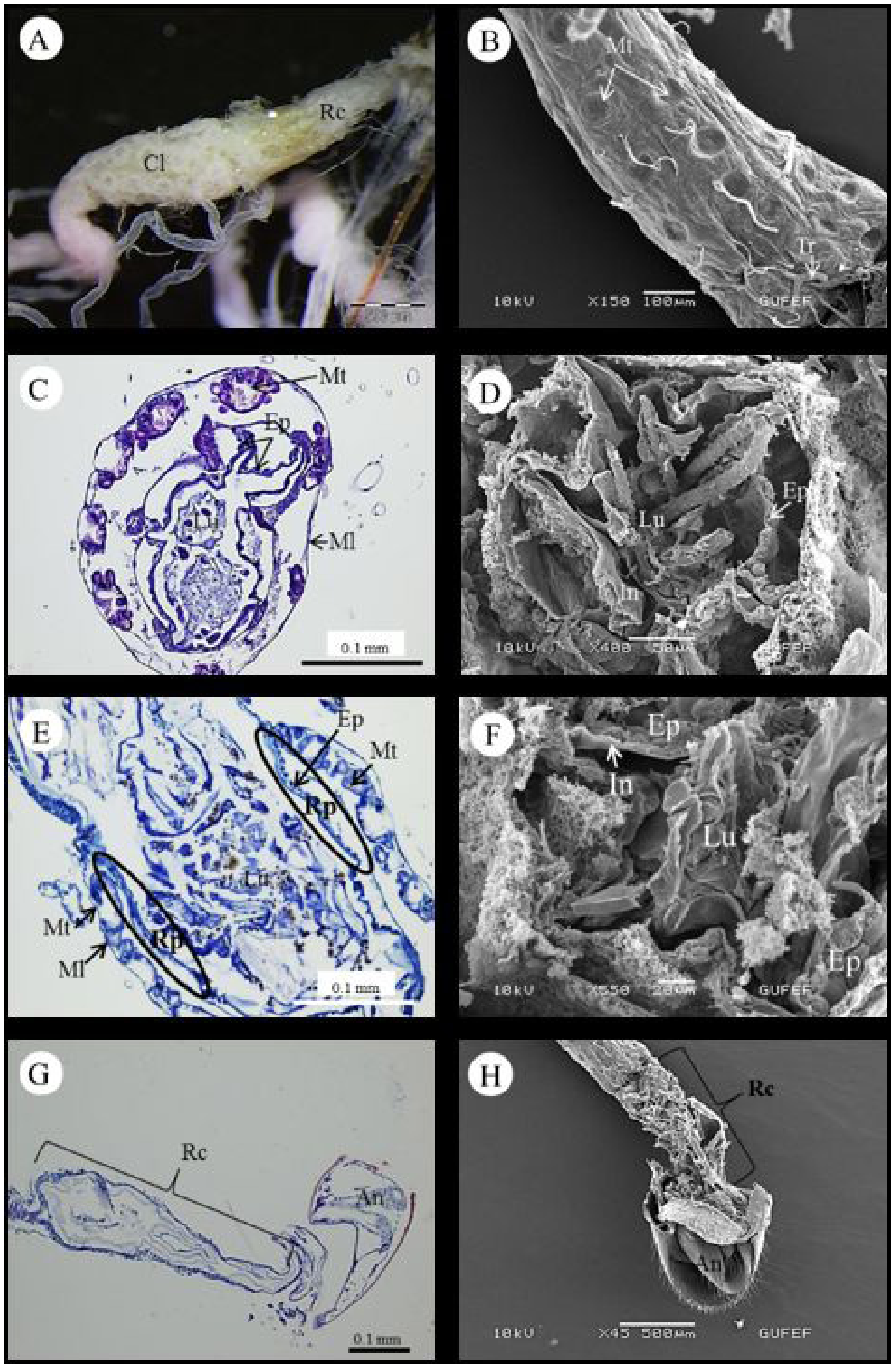

Figure 7 E. ovulum, adult: (A) General view of colon (SM), (B) Malpighian tubules (Mt) encapsulating the wall of the colon (Cl), (C) The histological section of colon showing intima (In), epithelium (Ep), Malpighian tubules (Mt), muscles (Ml) and lumen (Lu) (H\&E) (LM). (D) The cross section of the colon (SEM), (E) The histological section of rectum (Rc) showing intima (In), epithelium (Ep), rectal pad (Rp), Malpighian tubules (Mt), muscles (Ml) and lumen (Lu) is filled with fecal matter (H\&E) (LM), (F) Lumen (Lu), epithelium (Ep) and intima (In) in the rectum wall (SEM), (G,H) The connection of rectum (Rc) with anus (An) (H\&E) (LM) (SEM). H \& E-hematoxylin and eosine, LM-Light microscopy, SEM-Scanning electron microscopy, SM-stereo microscope. 
and morphologically, the epithelium of rectum is made up of large cuboidal cells. Internally, the epithelium is lined by intima and externally by muscles (Figs. 7E and F). The rectum opens exteriorly through an anus (Figs. 7G and $\mathrm{H}$ ).

\section{Discussion}

The Curculionidae (true weevils or snout weevils) are mostly plant feeders and are economically important pests of crops (Moon, 2015). Most beetles have mouth parts designed for chewing solid food. Many beetles of the superfamily Curculionoidea have mouthparts at the end of distinct snouts which are responsible for penetrating, feeding, and boring holes for egg-laying (Van Zandt et al., 2003; Moon et al., 2008). Mouthparts can be separated into two basic types: those adapted for biting and chewing solid food, and those adapted for sucking up fluids (Chapman, 1982; Moon et al., 2008). The mouthparts of E. ovulum are similar to the weevil ancestor or plesiomorphic. The mandibles in E. ovulum are very strong and have been modified to cut and chew. The mandibles are a pair of hard, often tooth-like structures that move horizontally to grasp, crush, or cut food (Moon, 2015).

The gross morphological features of the mouthparts of E. ovulum are generally similar to those reported for other weevils (Ting, 1933, 1936; Dennell, 1942; Morimoto, 1962; Morrone et al., 1992; Lyal, 1995; Bae, 2000; Bae et al., 2000; Morimoto and Kojima, 2003; Morimoto et al., 2006; Belhoucine et al., 2013; Moon, 2015). Two pairs of finger-like appendages (maxillary and labial palpi) are found around the mouth in most beetles, and they are responsible for moving food into the mouth. Each pair has lobed sensory palpi, which may detect olfactory stimuli (Moon, 2015; Ghany and Aziz, 2017).

The three parts of the E. ovulum gut (foregut, midgut and hindgut) are easily distinguishable and are similar to those seen in other Coleopterans (Sinha, 1958; Díaz et al., 1998, 2000, 2003; Rubio et al., 2008; Bu and Chen, 2009; Aldigail et al., 2013; Sarwade and Bhawane, 2013; Singh and Prasad, 2013; Borges et al., 2015; Candan et al., 2019).

Generally, in Curculionidae the foregut begins at the mouth followed by the pharynx, esophagus, crop and proventriculus. The foregut is responsible for the transport of food to the crop whose function is the temporary storage of food (Díaz et al., 2000; Rubio et al., 2008; Bu and Chen, 2009; Aldigail et al., 2013; Singh and Prasad, 2013; Sousa et al., 2013; Candan et al., 2019). Various authors have illustrated subtle differences among species (Sinha, 1958; Vazquez-Arista et al., 1997; Díaz et al., 1998, 2000, 2003; Rubio et al., 2008; Bu and Chen, 2009; Aldigail et al., 2013; Sarwade and Bhawane, 2013; Singh and Prasad, 2013; Borges et al., 2015; Candan et al., 2019). The spines observed within the esophageal intima of E. ovulum were similar to those observed in A.diaperinus (Coleoptera: Tenebrionidae), Dendroctonus micans, D. ponderosae, D. pseudotsugae pseudotsugae, D. rufipennis and D. terebrans (Coleoptera: Scolytidae) (McAllister et al., 1995; Díaz et al., 2003). In contrast, the esophageal intima of $P$. belli (Coleoptera: Tenebrionidae) lacks spines (Sarwade and Bhawane, 2013). The morphology the proventriculus of E. ovulum was similar to that of other weevils; the lumen contained eight sclerotized teeth extending from the intima. The intima is covered with a layer of epithelial cells and circular and longitudinal muscle layers as other species of Curculionoidea superfamily (Dennell, 1942; Eaton, 1942; Baker, 1984; Sánchez et al., 2000; Rubio et al., 2008; Bu and Chen, 2009; Sousa et al., 2013). The muscles are responsible for constriction of the proventriculus during the mortaring and filtering of food as can be seen in E. ovulum. Similar structures were also described by Díaz et al. (1998, 2000, 2003), Bu and Chen (2009) and Sousa et al. (2013).

The midgut of E. ovulum is subdivided into easily distinguished anterior and posterior parts. Both anterior midgut and posterior midgut are tube-shaped. The anterior midgut is wide whereas the posterior one is long and tube-shaped. This is similar to that described for other
Coleoptera species (Díaz et al., 1998, 2000, 2003; Rubio et al., 2008; Singh and Prasad, 2013; Candan et al., 2019). The anterior midgut is responsible for allowing a sufficient mixture of digestive enzymes and food. The posterior midgut, with gastric caeca, helps to increase the efficiency of absorption. In E. ovulum the midgut epithelium is a layer of columnar cells, as in other species (Khan, 1964; Smith et al., 1969; $\mathrm{Bu}$ and Chen, 2009). The gastric caeca bear many papillae which are appearing as finger-like tubular structures. Their position, number, and arrangement vary among coleopteran species (Calder, 1989; Rubio et al., 2008). Gastric caeca are found on the posterior midgut in E. ovulum. A similar structure was observed to E. malachiticus (Coleoptera, Curculionidae) (Candan et al., 2019). No midgut caeca was observed in A. diaperinus (Coleoptera: Tenebrionidae) and Epilachna chrysomelina Fabr. (Coleoptera: Coccinellidae) (McAllister et al., 1995; Aldigail et al., 2013). In Hypothenemus hampei (Ferrari) (Coleoptera, Curculionidae), the posterior midgut is characterized by the presence of two gastric caeca (Rubio et al., 2008). However, Bu and Chen (2009) stated that approximately 160 gastric caeca are located in the middle of the midgut of Dendroctonus armandi (Coleoptera: Curculionidae).

In Coleopterans, both the front and posterior part of the digestive canal are characterized by presence of Malpighian tubules; they also occur between the mid- and hind-gut, (Sinha, 1958; McAllister et al., 1995; Díaz et al., 2000, 2003; Rubio et al., 2008; Bu and Chen, 2009; Aldigail et al., 2013; Singh and Prasad, 2013; Candan et al., 2019). In E. ovulum, there are six long tubular Malpighian tubules with smooth surfaces. Histologically they are composed of large cells with large, oval nuclei. Similar structures have been observed in other Coleopteran species (Sinha, 1958; McAllister et al., 1995; Díaz et al., 2000, 2003; Rubio et al., 2008; Bu and Chen, 2009; Aldigail et al., 2013; Singh and Prasad, 2013; Candan et al., 2019). The cryptonephridial system attached to the hindgut wall of E. ovulum is similar to that of Dendroctonus parallelocollis, D. rhizophagus, and D. valens (Coleoptera, Curculionidae: Scolytinae) (Díaz et al., 1998), D. armandi (Bu \& Chen, 2009), E. chrysomelina (Coleoptera: Coccinellidae) (Aldigail et al., 2013), and Odoiporus longicollis (Coleoptera: Curculionidae) (Singh \& Prasad, 2013).

As in other Coleopterans, the hindgut in E. ovulum consists of pylorus, ileum, colon and rectum (Sinha, 1958; Aldigail et al., 2013; Candan et al., 2019). In A. diaperinus (Coleoptera: Tenebrionidae), hindgut is divided into two distinct sections, the anterior small intestine and the posterior large intestine (McAllister et al., 1995). Borges et al. (2015) pointed out that the hindgut in $A$. bipunctata is composed of the ileum, rectum and rectal canal. The main functions of the hindgut are the absorption of water, salts from the feces and urine (Smith, 1968).

In the present study, the morphology of mouthparts, and the morphology and histology of the alimentary of $E$. ovulum were examined. These results were compared with those of other species of Curculionidae. It is hoped that this study will contribute to the knowledge of the digestive system of Curculionidae. Furthermore it is hoped that characters revealed may be useful in future studies; and provide information for future research into the ecology and biological control of noxious Coleoptera.

\section{Acknowledgments}

I wish to acknowledge Dr. Robert Lavigne (Professor Emeritus, University of Wyoming, Laramie, Wyoming, U.S.A.) for linguistic improvement.

\section{Conflicts of interest}

The authors declare no conflict of interest for the authorship and/ or publication of this article. 


\section{Author contribution statement}

All authors contributed to this review. Conduct of experiments (NÖK), writing of the manuscript (SC, ME).

\section{References}

Aldigail, S. A., Alsaggaff, A. I., Al-Azab, A. M., 2013. Anatomical and histological study on the digestive canal of Epilachna chrysomelina (Coleoptera: coccinellidae). Biosci. Biotechnol. Res. Asia 10 (1), 183-192.

Bae, J. D., 2000. Comparative morphology of the mouthparts of the Curculionoidea (Coleoptera), their feeding mechanism and relationship to classification. Part I. Family Brentidae. Korean J. Entomology 18, 133-144.

Bae, J. D., Park, S. O., Lee, J. E., 2000. Comparative morphology of the mouthparts of the Curculionoidea (Coleoptera), their feeding mechanism and relationship to classification. Part II. Family Apionidae. Korean J. Entomology 18, 145-151.

Baker, P. S., 1984. Some aspects of the behaviour of the coffee berry borer in relation to its control in southern Mexico (Coleoptera: scolytidae). Folia Entomol. Mex. 61, 9-24.

Belhoucine, L., Bouhraouaa, R. T., Pratsb, E., Pulade-Villarc, J., 2013. Fine structure and functional comments of mouthparts in Platypus cylindrus (Col., Curculionidae: platypodinae). Micron 45, 74-82.

Bolu, H., 2016. Southern Anatolia Region Insect Fauna I (Coleoptera II: Curculionidea, Tenebrionoidea) of Turkey. Poljopr. Sumar. 62 (3), 73-91.

Borges, I., Nóia, M., Camarinho, R., Rodrigues, A. S., Soares, A. O., 2015. Characterization of the alimentary canal of the aphidophagous ladybird, Adalia bipunctata(Coleoptera: Coccinellidae): anatomical and histological approaches. Entomol. Sci. 18 (1), 66-73.

Bu, S. H., Chen, H., 2009. The Alimentary canal of Dendroctonus armandi Tsai and Li (Coleoptera: Curculionidae: Scolytinae). Coleopt. Bull. 63 (4), 485-496.

Caldara, R., 1990. Revision taxonomica della specie paleartiche del genere Tychius Germar (Coleoptera: curculionidae). Mem. Soc. Ital. 25 (3), 45-217.

Calder, A. A., 1989. The alimentary canal and nervous system of Curculionoidea (Coleoptera): gross morphology and systematic significance. J. Nat. Hist. 23 (6), 1205-1265.

Candan, S., Özyurt Koçako lu, N., Erbey, M., 2019. Morphology and histology of the alimentary canal of Epiphaneus malachiticus Boheman, 1842 (Coleoptera, Curculionidae). Entomol. Rev. 99 (3), 326-336.

Chapman, R. F., 1982. The Insect: Structure and Function. Hodder and Stoughton, London, pp. 330-349.

Chen, F., Zhang, C., Dai, W., 2016. Fine structure and sensory apparatus of the mouthparts of the maize weevil, Sitophilus zeamais Motschulsky (Coleoptera: Curculionoidea: Dryophthoridae). Ann. Entomol. Soc. Am. 109 (6), 881-889.

Crowson, R. A., 1981. The Biology of Coleopteran, Academic Press, London.

Dadd, R. H., 1970. Digestion in insects in chemical zoology. In: Florrin, M., Secheer, B.T. (Eds.), Arthropoda, Academic Press, New York, pp. 117-145.

Dennell, R., 1942. The structure and function of the mouthparts, rostrum and fore-gut of the weevil, Calandra granaria L. Philos. Trans. R. Soc. Lond. B Biol. Sci. 231, 247-291.

Díaz, E., Arciniega, O., Sánchez, L., Cisneros, R., Zúñiga, G., 2003. Anatomical and histological comparison of the alimentary canal of Dendroctonus micans, D. ponderosae, D. pseudotsugae pseudotsugae, D. rufipennis, and D. terebrans (Coleoptera: scolytidae). Ann. Entomol. Soc. Am. 96 (2), 144-152.
Díaz, E., Cisnero, R., Zuñiga, G., Uria-Galicia, E., 1998. Comparative anatomical and histological study of the alimentary canal of Dendroctonus parallelocollis, D. rhizophagus, and D. valens (Coleoptera: scolytidae). Ann. Entomol. Soc. Am. 91 (4), 479-487.

Díaz, E., Cisneros, R., Zúñiga, G., 2000. Comparative anatomical and histological study of the alimentary canal of the Dendroctonus frontalis (Coleoptera: Scolytidae) complex. Ann. Entomol. Soc. Am. 93 (2), 303-311.

Eaton, C. B., 1942. The anatomy and histology of the proventriculus of Ips radiatae Hopkins (Coleoptera: scolytidae). Ann. Entomol. Soc. Am. 35, 41-49.

Ekis, G., Gupta, A. P., 1971. Digestive system of Cleridae (Coleoptera). Int. J. Insect Morphol. Embryol. 1 (1), 51-86.

Garayoa, M., Villaro, A. C., Montuenga, L., Sesma, P., 1992. Malpighian tubules of Formica polyctena Hymenoptera: light and electron microscopic study. J. Morphol. 214, 159-171.

Ghany, N. M., Aziz, S. E., 2017. External Morphology of Antennae and Mouthpart Sensillae of the Granary Weevil (Coleoptera: curculionidae). J. Entomol. Sci. 52 (1), 29-38.

Gilmour, D., 1961. The Biochemistry of Insects. Academic Press, New York. Gullan, P. J., Cranston, P. S., 2005. The Insects: an Outline of Entomology, 3rd ed. Blackwell, Malden, MA.

Hoffmann, A., 1950. Faune de France, Coleopteres, Curculionides, Premiere Partie 52. Lechevalier, Paris.

Kasap, H., 1978. A comparative anatomical study of the alimentary canal of chrysomeloidea (Coleoptera: Polyphaga). Fac. des Sciences de l'Univ. d'Ankara. 22, 53-78.

Khan, M. A., 1964. Histological changes related to the secretion of digestive enzymes in the midgut and caeca of Locusta migratoria L. (Orthoptera: Acrididae). Proc. R. Ent. Soc. Lond. 9, 118-124.

Kissinger, D. G., 1963. The proventricular armature of Curculionidae (Coleoptera). Ann. Entomol. Soc. Am. 56, 769-771.

Lodos, N., Önder, F., Pehlivan, E., Atalay, R., Erkin, E., Karsavuran, Y., Tezcan, S., Aksoy, S., 2003. Faunistic Studies on Curculionidae (Coleoptera) of Western Black Sea, Central Anatolia and Mediterranean Regions of Turkey, Meta Basım Matbaacılık Hizmetleri, İzmir.

Lyal, C. H. C., 1995. The ventral structures of the weevil head (Coleoptera: curculionoidea). Mem. Entomol. Soc. Wash. 14, 35-51.

Maddrell, S. H. P., Gardiner, B. O. C., 1980. The permeability of the cuticular lining of the insect alimentary canal. J. Exp. Biol. 87, 227-237.

McAllister, J. C., Steelman, C. D., Carlton, C. E., 1995. Histomorphology of the larval and adult digestive systems of Alphitobius diaperinus (Coleoptera: tenebrionidae). J. Kans. Entomol. Soc. 68 (2), 195-205.

Mihajlova, B., 1978. Contrubition to the study of fauna of snout beetles (Coleoptera: Curculionidae) of Macedonia. Fragmen. Balk. 10 (14), 1-234.

Moon, M. J., 2015. Microstructure of mandibulate mouthparts in the greater rice weevil, Sitophilus zeamais (Coleoptera: curculionidae). Entomol. Res. 45, 9-15.

Moon, M. J., Park, J. G., Kim, K. H., 2008. Fine structure of the mouthparts in the ambrosia beetle Platypus koryoensis (Coleoptera: Curculionidae: Platypodinae). Anim. Cells Syst. 12, 101-108.

Morimoto, K., 1962. Comparative morphology and phylogeny of the superfamily Curculionoidea of Japan. J. Fac. Agric. 11, 331-373.

Morimoto, K., Kojima, H., 2003. Morphological characters of the weevil head and phylogenetic implications (Coleoptera, Curculionoidea). Esakia 43, 133-169.

Morimoto, K., Kojima, H., Miyakawa, S., 2006. The Insects of Japan. Curculionoidea: General Introduction and Curculionidae: Entiminae (Part 1). Phyllobiini, Polydrusini and Cyphicerini (Coleoptera). Vol. 3. Touka Shobo Co., Ltd, Fukuoka, Japan. 
Morrone, J. J., Diaz, N. B., Loiacono, M. S., 1992. Comparative morphology of mouthparts in the tribe Listroderini (Coleoptera: curculionidae). Elytron 6, 47-59.

Romoser, W. S., Stoffolano, J. G., 1998. The Science of Entomology, 4th ed. McGraw-Hill, Boston.

Ross, A. H., 1963. The Beetles of the United States. The Catholic University of America, Washington D.C.

Rubio, J. D. G., Bustillo, P. A. E., Vallejo, E. L. F., Acuña, Z. J. R., Benavides, M. P., 2008. Alimentary canal and reproductive tract of Hypothenemus hampei(Ferrari)(Coleoptera: Curculionidae, Scolytinae). Neotrop. Entomol. 37 (2), 143-151.

Sánchez, P. A., Sánchez, F., Caetano, F. H., Jaffe, K., 2000. El tubo digestivo en adultos de Rhynchophorus palmarum(L.) (Coleoptera: Curculionidae): morfologõá y ultraestructura. Bol. Entomol. Venez. 15, 195-216.

Santos, C. G., Neves, C. A., Zanuncio, J. C., Serrão, J. E., 2009. Postembryonic development of rectal pads in bees (Hymenoptera, Apidae). Anat. Rec. 292, 1602-1611.

Sarwade, A. B., Bhawane, G. P., 2013. Anatomical and histological structure of digestive tract of adult Platynotus belli (Coleoptera: Tenebrionidae). In. Biol. Forum-An. Int. J. 5, 47-55.

Serrão, J. E., 2005. Proventricular structure in solitary bees (Hymenoptera: apoidea). Org. Divers. Evol. 5, 125-133.

Serrão, J. E., 2007. Proventricular structure in the bee tribe Augochlorini (Hymenoptera: halictidae). Org. Divers. Evol. 7, 175-180.

Serrão, J. E., Marques-Silva, S., Martins, G. F., 2004. The rectum of Oxaea flavescens (Andrenidae) has a specialized structure among bees. Micron 35, 245-253.

Singh, O. L., Prasad, B., 2013. Histomorphology of the alimentary tract of adult, Odoiporus longicollis (Oliv.) (Coleoptera: curculionidae). J. Entomol. Zoo. 1, 109-115.
Sinha, R. N., 1958. The alimentary canal of the adult of Tribolium castaneum Herbst (Coleoptera, Tenebrionidae). J. Kans. Entomol. Soc. 31 (2), 118-125.

Smith, D. S., 1968. Insect Cells, Their Structure and Function. Oliver and Boyd, Edinburgh, U.K.

Smith, D. S., Compiler, K., Janness, M., Lipton, C., White, L. W., 1969. Cellular organization and ferritin uptake in the midgut epithelium of moth, Ephestia kuhniella. J. Morphol. 127, 41-77.

Snodgrass, R. E., 1993. Principles of Insect Morphology, 2nd ed. Cornell University Press, New York.

Sousa, G., Scudeler, E. L., Abrahão, J., Conte, H., 2013. Functional Morphology of The Crop and Proventriculus of Sitophilus zeamais (Coleoptera: curculionidae). Ann. Entomol. Soc. Am. 106 (6), 846-852.

Ting, P. C., 1933. Feeding mechanisms of weevils, their function and relationship to classification. Mon. Bull. Dep. Agric. State Calif. 22, 161-165.

Ting, P. C., 1936. The mouth parts of the coleopterous group Rhynchophora. Microentomology 1, 93-114.

Van Zandt, P. A., Townsend, V. R., Carlton, C. E., Blackwell, M., Mopper, S., 2003. Loberus impressus (LeConte) (Coleoptera: Erotylidae) fungal associations and presence in the seed capsules of Iris hexagona. Coleopt. Bull. 57, 281-288.

Vazquez-Arista, M., Smith, R. H., Olalde-Portugal, V., Hinojosa, R. E., Hernandez-Delgadillo, R., Blanco-Labra, A., 1997. Cellulolytic bacteria in the digestive system of Prostephanus truncatus (Coleoptera: bostrichidae). J. Econ. Entomol. 90 (5), 1371-1376.

Wigglesworth, V. B. 1972. The Principles of Insect Physiology, 7th ed. John Wiley and Sons Inc., New York. 